\title{
A Case of Salivary Gland Choristoma Mimicking Glomus Tympanicum
}

\author{
Jong Hyun Lim, Moo Keon Kim, In Sik Kim, and Chul Won Park \\ Department of Otolaryngology-Head and Neck Surgery, School of Medicine, Hanyang University, Seoul, Korea
}

\section{고실 사구종과 혼동되었던 침샘 분리종 1 예}

임종현 · 김무건 · 김인식 · 박철원

한양대학교 의과대학 이비인후-두경부외과학교실

\author{
Received May 8, 2015 \\ Revised June 9,2015 \\ Accepted June 23, 2015 \\ Address for correspondence \\ Chul Won Park, MD, PhD \\ Department of Otolaryngology- \\ Head and Neck Surgery, \\ School of Medicine, \\ Hanyang University, \\ 222-1 Wangsimni-ro, Seongdong-gu, \\ Seoul 04763, Korea \\ Tel $+82-2-2290-8591$ \\ Fax $+82-2-2293-3335$ \\ E-mail cwpark@hanyang.ac.kr
}

Salivary gland choristoma is defined as the architecturally normal salivary gland tissues found in abnormal locations. Middle ear salivary gland choristoma usually presents with conductive hearing loss. We present a case of middle ear mass with conductive hearing loss in a 6-year-old boy. A reddish mass was incidentally found behind the normal tympanic membrane. Magnetic resonance image showed the markedly enhancing lesion which was in accordance with glomus tympanicum. Preoperative angiography was performed, but supplying artery and mass was not identified. Surgical exploration was made and the mass was dissected easily without profuse bleeding. Final diagnosis was salivary gland choristoma by histopathology. We discuss the clinical features and management of middle ear salivary choristoma with the review of literature.

Korean J Otorhinolaryngol-Head Neck Surg 2015;58(11):798-801

Key Words Choristoma · Glomus tympanicum · Middle ear mass · Salivary gland.

\section{서 론}

분리종이란 조직학적으로 정상인 조직이 본래의 위치가 아 닌 다른 곳에서 존재하는 것으로 정의하며, 비정상조직과 정 상조직이 혼합되어 있는 하마종과는 구분된다. 중이 내에서는 침샘 분리종, 교세포 분리종이 발생할 수 있으며, 이 중 중이 침샘 분리종은 정상적인 침샘이 중이공간에 존재하는 것을 의 미한다. 이러한 분리종은 병리학적으로만 진단이 가능하다.

중이 내 침샘 분리종은 매우 드문 질환으로 1961년 Taylor 와 $\operatorname{Martin}^{1)}$ 이 처음 보고한 이후 세계적으로 30여 예만이 보 고되고 있다. ${ }^{2,3)}$ 일반적으로 전도성 난청을 동반한 중이강내 종물로 관찰되며, 선천성 진주종, 고실 사구종, 안면신경 신 경수초종 등 다른 중이 종물들과 감별되어야 한다. ${ }^{4,5)}$ 하지만 중이 침샘 분리종에 대한 술전 진단 방법, 영상의학적 소견 에 대해서는 알려진 바가 없다.

저자들은 이내시경 소견과 자기공명영상 검사 결과상 고실
사구종으로 의심되었던 중이 침샘 분리종 1 예를 이내접근법 으로 성공적으로 제거하였기에 문헌고찰과 함께 보고하는 바이다.

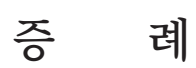

6세 남환이 우연히 발견된 좌측 고막내 종물을 주소로 본 원 이비인후과 외래로 내원하였다. 내시경 소견상 우측은 정 상 고막이었고 좌측 고막 안쪽에 붉은색의 종물이 확인되었 다(Fig. 1). 환아는 중이염의 과거력은 없었으며, 이루, 이명, 난청 등을 호소하지는 않았지만 순음청력검사상 좌측 기도 역치 $50 \mathrm{~dB}$, 골도역치 $5 \mathrm{~dB}$ 의 전음성 난청이 확인되었다(Fig. 2). 측두골 전산화단층촬영상 안면신경의 고실 분절과 닿아 있는 중이 종물이 확인되었으며, 안면신경관의 파괴도 관찰 되었다. 종물을 감별하고 안면신경과의 관계를 살펴보기 위해 측두골 자기공명영상 촬영을 시행였다. 종물은 $\mathrm{T} 2$ 강조영상 
에서 신호 증강되고 $\mathrm{T} 1$ 강조 조영증강 영상에서 강하게 신호 가 증강되는 양상으로 나타나 고실 사구종의 소견과 일치하 였다(Fig. 3). 고실사구종에 대한 수술적 치료를 계획한 후 수술 중 출혈을 예방하기 위해 혈관조영을 통한 중이 종물의 색전술을 시도하였다. 하지만 혈관조영술상 고실 사구종의 대표적인 영양 혈관으로 알려져 있는 상행인두동맥의 분지 및 그 외 다른 혈관을 따라 조영되는 종물이 관찰되지 않아 색전술을 시행하지 않았다(Fig. 3). 이에 탐색적 고실 절개술

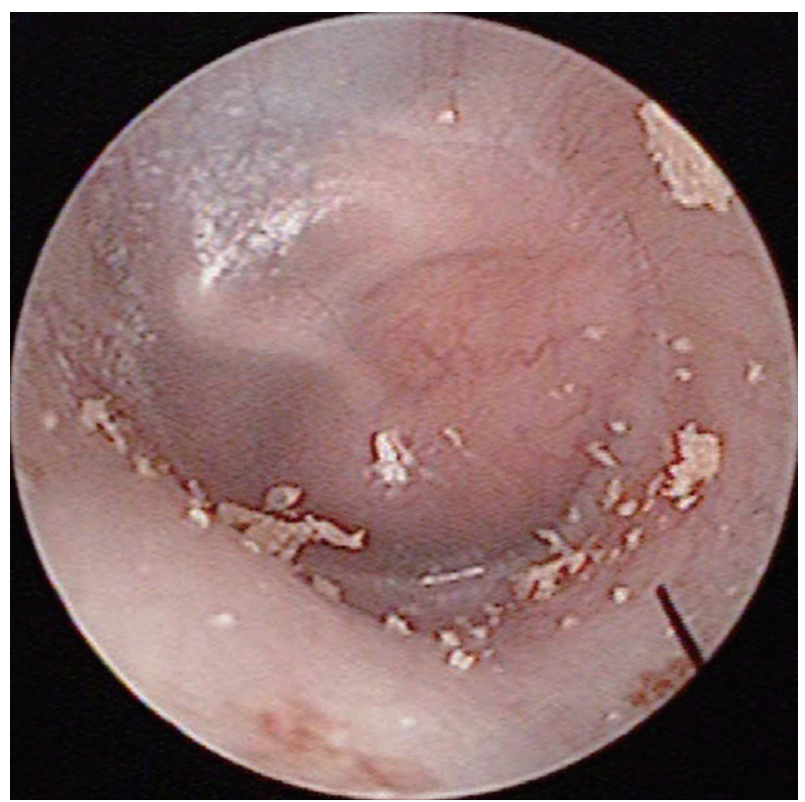

Fig. 1. Otoendoscopic image of left tympanic membrane. The pinkish mass was identified behind the normal tympanic membrane.

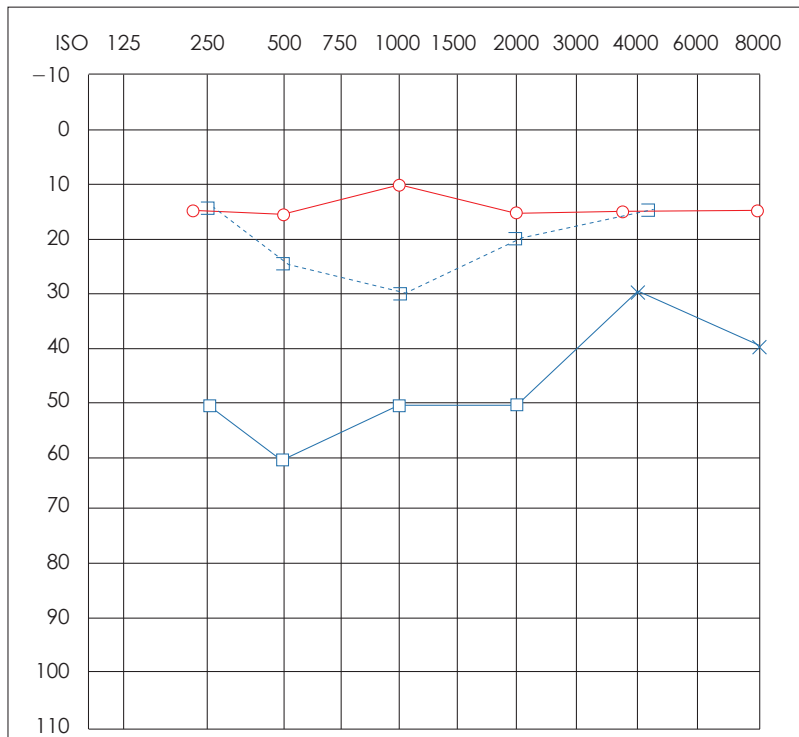

A

Fig. 2. Pure tone audiogram. Preoperative PTA (A). Postoperative PTA (B). PTA: pure tone audiometry.
을 통하여 종물을 확인하고, 가능할 경우 절제하기로 계획하 고 전신마취하 이내절개를 통해 수술을 진행하였다. 수술 중 고실 개방 시 중이강 내에서 매우 끈적한 점액이 흘러나왔고 고막 내측에 약 $1.0 \mathrm{~cm}$ 크기의 매끄럽고 캡슐화된 종물이 확인되었다. 종물 제거 시 출혈은 거의 없었으며 주위 조직과 비교적 잘 박리되었으나 안면신경과는 유착되어 있었다. 또 한 추골, 등골은 학인되지 않았고, 안면신경이 안면신경관으로 부터 불거져 나와 난원창을 덮고 있는 것이 관찰되었다. 종물 의 무리한 제거가 안면신경에 손상을 줄 가능성이 높을 것으 로 판단되어 안면신경과 유착된 부분은 안면신경 자극기를 이용하여 안면신경을 확인한 후 종물을 분할 절제(piecemeal resection)하였고 동결절편 검사를 의뢰하였다(Fig. 4). 동결 절편 검사상 종물은 선종, 안면신경에 접해있던 부분은 지방 조직으로 확인되어 수술을 종료하였다. 술 후 안면신경의 손 상은 관찰되지 않았으며, 병리조직검사 결과는 침샘 분리종 으로 확진되었다(Fig. 5). 술 후 약 5개월간 종물이 재발하거 나 증식한 소견은 관찰되지 않으며 청력은 술 전과 큰 차이 가 없는 상태로 외래 추적관찰 중이다(Fig. 2).

\section{고 찰}

침샘 분리종은 두경부에서 다양한 위치에서 나타날 수 있으 나 중이 내에 생기는 경우는 매우 드문 것으로 알려져 있다. ${ }^{6,7)}$

침샘 분리종의 병인은 정확히 알려진 바는 없지만 비정상적 인 배아 발생으로 인해 유발된 것으로 생각한다. 대타액선은 구강상피 아체(epithelial bud)로부터 기원하여 간충조직으로

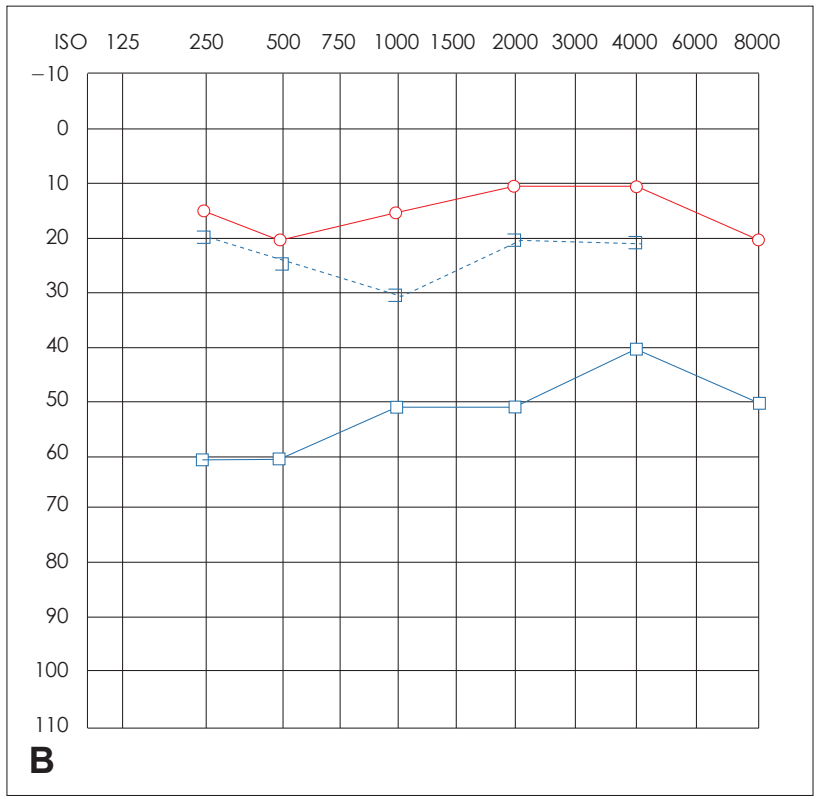



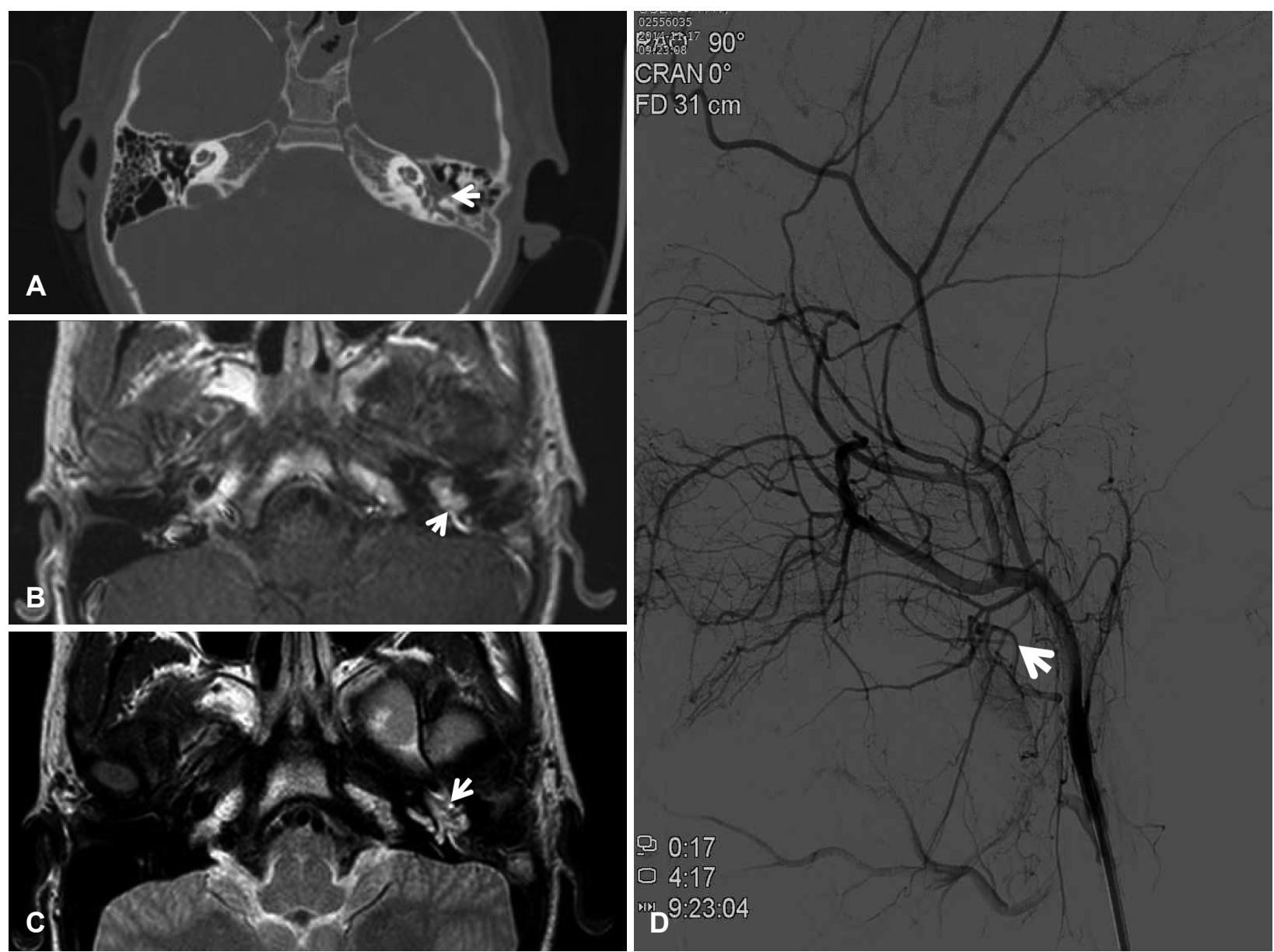

Fig. 3. Computed tomogram and magnetic resonance image of temporal bone. Soft tissue density with facial canal dehiscence in CT (arrow) (A). Middle ear mass with markedly high intense in T1 enhanced image (arrow) (B). Mass with high intense signal in T2 weighted image (arrow) (C). Angiography demonstrated no vascular lesion around the territories of ascending pharyngeal artery (arrow) which is the most common nutrient vessel of glomus tympanicum (D).

이동하면서 발생하는 반면, 소타액선은 구강의 내배엽, 외배엽 세포들로 도관(duct)과 선포(acini)가 만들어져 구인두 전체에 분포하게 된다. ${ }^{8}$ 침샘으로 발생될 외배엽 조직이 발생과정 중 측두골 내에서 빠져나가지 못한 경우, 침샘 분리종이 발생할 수 있으며 선천성 진주종과 비슷한 병인으로 설명한다." 또한 침샘 분리종 환자들이 제 2 아가미궁의 발생과정 중의 문제가 침샘 분리종과 연관이 있을 것이라는 가설도 있다.) 본 증례 에서도 제 2 아가미궁 기원의 구조인 등골의 상부구조, 침골의 장각이 관찰되지 않았다.

중이 침샘 분리종은 일반적으로 전도성 난청을 주소로 하며 이루, 이명 등이 동반될 수 있다. 이소골의 기형은 다양하게 관 찰되며, 안면신경은 안면신경관이 파괴되거나 안면신경 주행 의 이상으로 나타날 수 있다. ${ }^{10,11}$

선천성 진주종, 사구종양, 신경종, 유피낭종, 림프종 등 중이 에 발생할 수 있는 다른 질환들과 감별이 필요하지만 침샘 분 리종의 경우 병리조직 결과만으로 확진할 수 있어 임상 양상만
으로 침샘 분리종을 생각하는 것은 매우 어려운 일이다. ${ }^{12}$

중이 종물의 진단에는 측두골 전산화단층촬영이 도움이 된다. 하지만 혼합성 난청이 있거나 선천성, 혈관성 기형이 의심 되는 경우, 또는 종물과 안면신경과의 관계를 파악하기 위해 자기공명영상 촬영을 고려할 수 있다. ${ }^{13)}$

기존 문헌들에는 침샘 분리종의 자기공명영상 소견이 정립 되어 있는 바가 없었다. 다만 일반적인 정상 침샘의 자기공명 영상 소견, 특히 이하선의 경우 지방 조직이 포함되어 있어 $\mathrm{T} 1$ 및 T2 강조영상에서 고강도 신호를 보여 이를 통해 침샘 분리 종의 자기공명영상 소견을 유추해볼 수 있다. 고실 사구종의 경우는 자기공명영상 $\mathrm{T} 1$ 강조영상에서 등강도 혹은 저강도 의 신호를 나타내며, T2 강조영상에서 고강도 신호를 보이고 $\mathrm{T} 1$ 강조 조영증강영상에서는 조영증강이 매우 잘된다. ${ }^{14)}$ 따라 서 자기공명영상 소견만으로는 이 둘의 감별 진단이 어려울 수 있다.

본 증례의 경우 자기공명영상 결과가 고실 사구종과 매우 유 


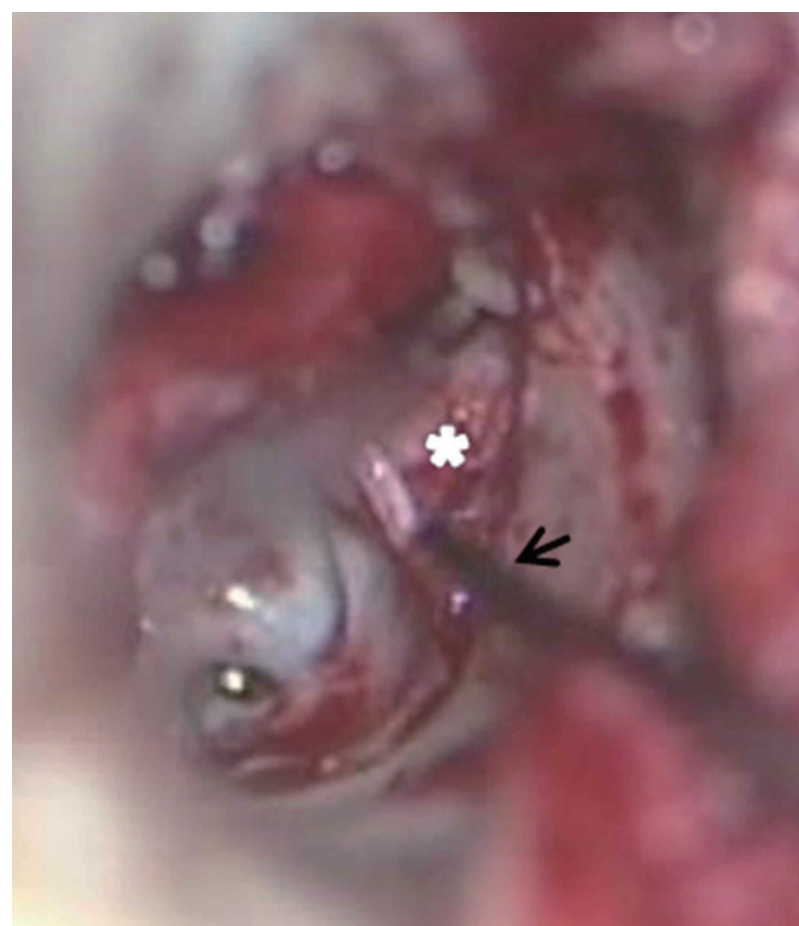

Fig. 4. Intraoperative finding. The tumor (asterisk) was adhered to faicial nerve. Nerve stimulator was checked boundary of facial nerve (arrow).

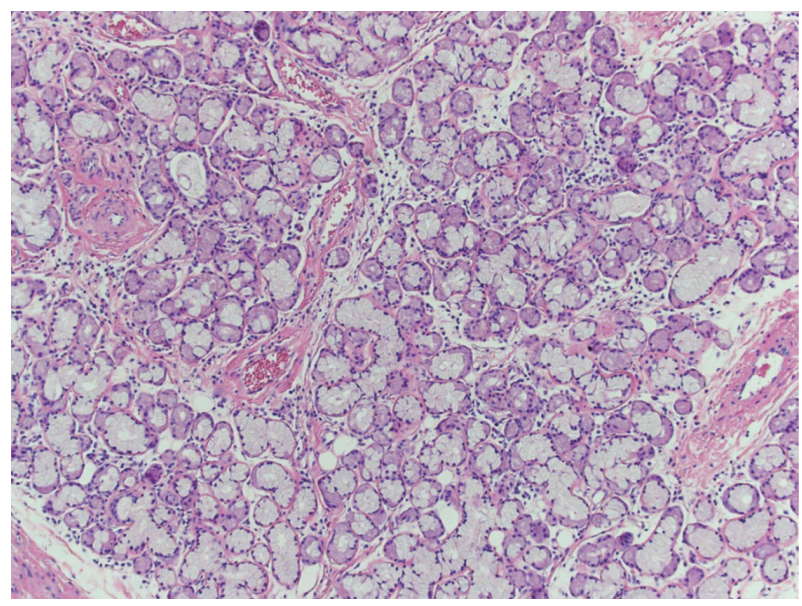

Fig. 5. Histologic finding of the middle ear mass (magnification: $\times 100$ ). Normal salivary gland tissue with adipose tissue, goblet cell, and duct structures was identified.

사한 양상을 보여 진단 초기 고실 사구종을 의심하였으며 확 진을 위해 혈관조영술을 시행하였다. 하지만 혈관조영술상 영 양 혈관과 조영되는 종물이 보이지 않아 고실 사구종의 가능 성이 낮다고 판단하여 탐색적 고실절개술을 계획하게 되었으 며, 조직병리학적 결과 침샘 분리종으로 진단할 수 있었다.

침샘 분리종은 조직학적으로 양성 병변으로 악성화가 보고
된 바는 없다. ${ }^{11)}$ 따라서 치료는 수술적 제거만으로 충분하다. 하지만 Buckmiller 등 ${ }^{15)}$ 에 따르면 중이내 침샘 분리종 환자 의 85\%에서 안면신경의 주행이상이나 열개(dehiscence)가 동 반된다는 보고가 있어 수술 중 안면신경 모니터링을 사용하 여 안면신경의 손상을 최소화하여야 한다. 그리고 불완전하 게 제거된 경우도 잔여 종물이 커지거나 악화되었다는 보고 가 없으므로, 본 증례와 같이 안면신경과 유착이 심한 경우는 부분 절제만으로도 충분할 것으로 사료된다.

중이 종물의 적절한 치료법과 수술법을 정하기 위해서는 수 술 전 감별진단이 매우 중요하다. 본 증례와 같이 수술 전 충 분한 영상의학적 검사가 종물의 진단 및 치료의 방향 결정에 중요한 역할을 할 수 있다. 또한 수술 중의 동결절편 검사를 통해 수술 중 절제 범위 결정 및 예후 예측에 도움이 될 수 있 을 것이다.

\section{REFERENCES}

1) Taylor GD, Martin HF. Salivary gland tissue in the middle ear. A rare tumor. Arch Otolaryngol 1961;73:651-3.

2) Rinaldo A, Ferlito A, Devaney KO. Salivary gland choristoma of the middle ear. A review. ORL J Otorhinolaryngol Relat Spec 2004;66 (3):141-7.

3) Fois P, Giannuzzi AL, Paties CT, Falcioni M. Salivary gland choristoma of the middle ear. Ear Nose Throat J 2014;93(10-11):458-64.

4) Kartush JM, Graham MD. Salivary gland choristoma of the middle ear: a case report and review of the literature. Laryngoscope 1984; 94(2 Pt 1):228-30.

5) Morimoto N, Ogawa K, Kanzaki J. Salivary gland choristoma in the middle ear: a case report. Am J Otolaryngol 1999;20(4):232-5.

6) Batsakis JG. Adenomatous tumors of the middle ear. Ann Otol Rhinol Laryngol 1989;98(9):749-52.

7) Ha SL, Shin JE, Yoon TH. Salivary gland choristoma of the middle ear: a case report. Am J Otolaryngol 2000;21(2):127-30.

8) Sperber GH. Craniofacial Embryology. 4th ed. London: Butterworths; 1989. p.185-91.

9) Peron DL, Schuknecht HF. Congenital cholesteatomata with other anomalies. Arch Otolaryngol 1975;101(8):498-505.

10) Abadir WF, Pease WS. Salivary gland choristoma of the middle ear. J Laryngol Otol 1978;92(3):247-52.

11) Namdar I, Smouha EE, Kane P. Salivary gland choristoma of the middle ear: role of intraoperative facial nerve monitoring. Otolaryngol Head Neck Surg 1995;112(4):616-20.

12) Ookouchi Y, Honda N, Gyo K. Salivary gland choristoma of the middle ear in a child: a case report. Otolaryngol Head Neck Surg 2003;128(1):160-2.

13) Maroldi R, Farina D, Palvarini L, Marconi A, Gadola E, Menni K, et al. Computed tomography and magnetic resonance imaging of pathologic conditions of the middle ear. Eur J Radiol 2001;40(2): 78-93.

14) Bierry G, Riehm S, Marcellin L, Stierlé JL, Veillon F. Middle ear adenomatous tumor: a not so rare glomus tympanicum-mimicking lesion. J Neuroradiol 2010;37(2):116-21.

15) Buckmiller LM, Brodie HA, Doyle KJ, Nemzek W. Choristoma of the middle ear: a component of a new syndrome? Otol Neurotol 2001;22(3):363-8. 